\title{
KARAKTERISTIK FERMENTATIF MEDIUM deMann Rogosa Sharpe (MRS) ANTOSIANIN BERAS KETAN HITAM (Oryza sativa var. glutinosa) MENGGUNAKAN Pediococcus pentosaceus N11.16
}

\author{
Fermentative Characteristic of deMan Rogosa Sharpe (MRS) Medium Containing Anthocyanin of Black \\ Glutinous Rice (Oryza sativa var. glutinosa) Using Pediococcus pentosaceus N11.16
}

\author{
Nanik Suhartatik ${ }^{1}$, Merkuria Karyantina', Muhammad Nur Cahyanto², Sri Raharjo², Endang Sutriswati Rahayu² \\ ${ }^{1}$ Fakultas Teknologi Pertanian, Universitas Slamet Riyadi Surakarta, \\ Jl. Sumpah Pemuda 18 Joglo Kadipiro, Surakarta 57136 \\ ${ }^{2}$ Jurusan Teknologi Pangan dan Hasil Pertanian, Fakultas Teknologi Pertanian, \\ Universitas Gajah Mada, Jl. Flora No. 1, Bulaksumur, Yogyakarta 55281 \\ Email: n_suhartatik@yahoo.com
}

\begin{abstract}
ABSTRAK
Langkah awal dalam metabolisme antosianin, komponen bioaktif utama yang terdapat dalam beras ketan hitam, adalah hidrolisis menjadi antosianidin (aglikon) dengan memanfaatkan enzim $\beta$,D-glukosidase. Pediococcus pentosaceus N11.16 merupakan salah satu bakteri yang telah diisolasi dan teruji kemampuannya untuk menghidrolisis antosianin beras ketan hitam. Penelitian ini bertujuan untuk mempelajari karakteristik fermentatif medium fermentasi yang mengandung antosianin beras ketan hitam menggunakan bakteri asam laktat P. pentosaceus N11.16. Penelitian dilakukan dengan cara menguji kemampuan tumbuh isolat dalam medium MRS yang dimodifikasi (MRSm) dengan penambahan antosianin beras ketan hitam. Hasil menunjukkan bahwa bakteri P. pentosaceus N11.16 mampu tumbuh dengan baik dalam medium MRS yang mengandung antosianin beras ketan hitam. Kenaikan mencapai 2 log cycle dengan aktivitas antioksidan (\%RSA) mencapai 75\% dan kemampuan menangkap logam mencapai 36,75\%. Total fenol medium MRSm+antosianin mencapai $584,05 \mathrm{mg}$ asam galat/100 mL medium setelah 16 jam fermentasi. Total fenol medium MRSm+antosianin cenderung lebih tinggi daripada MRSm atau kontrol (MRS). Aktivitas enzim $\beta$ glukosidase sel bakteri cenderung lebih tinggi pada medium MRSm+antosianin daripada MRSm atau kontrol (MRS).
\end{abstract}

Kata kunci: Antosianin, beras ketan hitam, bakteri asam laktat, antioksidan

\begin{abstract}
Anthocyanin was a bioactive compound which has an anti-inflammatory effect, anticancer, antimutagen, antioxidant, anticholesterol, and also acts as therapheutic agent for artherioschlerosis. Initial step for anthocyanin metabolism was hydrolyzed to anthocyanidin (aglikon) by $\beta$-D-glucosidase. Pediococcus pentosaceus N11.16 is known to be one of bacteria which has a capability to hydrolyze black glutinous rice anthocyanin extract. The aims of this research were to study the fermentative characteristics of MRS containing black glutinous rice anthocyanin medium (MRSm+Anthocyanin) using lactic acid bacteria P. pentosaceus N11.16. The results showed that P. pentosaceus N11.16 could grew well in this medium. Total acid producing bacteria increased untill $2 \log$ cycle with antioxidant activity (\%RSA) $75 \%$ and the $\mathrm{Fe}^{3+}$ ion reducing capacity $36.75 \%$. Phenolic compound in the MRSm+ anthocyanin was 584.05 $\mathrm{mg}$ asam galat $/ 100 \mathrm{~mL}$ after being fermented for 16 hours. Phenolic compound in MRSm+anthocyanin medium were higher than MRSm or control medium (MRS). Beta glucosidase activities of the bacterial cell tend to be higher in the MRS anthocyanin medium than MRS without sugar and control medium.
\end{abstract}

Keywords: Anthocyanin, black glutinous rice, lactic acid bacteria, antioxidant 


\section{PENDAHULUAN}

Antosianin merupakan komponen warna utama dalam bahan pangan yang dapat menimbulkan warna ungu, biru, hingga merah kehitaman. Antosianin merupakan turunan polihidroksil atau polimetoksi dari 2-phenyl-benzopyrylium. Antosianin yang ada di dalam tanaman berada dalam bentuk glikosida terikat dengan komponen gula (Avila dkk., 2009). Berdasarkan penelitian yang telah dilakukan sebelumnya dilaporkan bahwa bioavailabilitas antosianin sangat rendah dibandingkan dengan jenis flavonoid lain (Matsumoto dkk., 2001; McGhie dkk., 2003; Nielsen dkk., 2003; Manach dkk. 2005). Antosianin yang dikonsumsi akan dikeluarkan dari tubuh dalam bentuk terikat dengan molekul gula (glikosida) dan tidak dimetabolisme oleh tubuh. Hidrolisis glikosida antosianin merupakan langkah awal dalam degradasi dan absorbsi antosianin di dalam tubuh (Keppler \& Humpf, 2005). Beberapa hasil penelitian menunjukkan bahwa spesies bakteri asam laktat menunjukkan aktivitas enzim glukosidase dan berpartisipasi dalam hidrolisis glikosida makanan (Otieno dkk., 2005; Jeon dkk., 2002; Matsuda dkk., 1994. Avila dkk., 2009).

Konsumsi antosianin dalam diet terbukti mampu memberikan efek perlindungan terhadap penyakit kardiovaskuler, diabetes militus, antioksidan anti inflammasi, dan antikanker (Kano dkk., 2005; Matsui dkk., 2002; Oki dkk., 2002; Wang dan Stoner, 2009; Bagchi dkk., 2004; Ghiselli dkk., 1998). Sebagai antitumor dan antikanker, antosianin terbukti mampu menekan pertumbuhan sel HCT-15 (Kamei dkk., 1998) dan HL-60 (Katsube dkk., 2003).

Salah satu sumber antosianin yang berpotensi untuk dikembangkan di Indonesia adalah beras berwarna. Saat ini telah dikenal beberapa jenis beras yang kaya akan antosianin, seperti beras hitam, beras merah, beras ketan hitam (Oryza sativa L. cv Kam Doi Saked), dan lain-lain (Itani dan Ogawa, 2004; Ling, dkk., 2001; Perera dan Jansz, 2000). Pemanfaatan antosianin beras ketan hitam sebagai bahan pewarna alami bahan pangan belum banyak dikembangkan. Beras ketan hitam biasanya digunakan sebagai bahan dasar untuk membuat camilan atau snack, seperti brownies, tape ketan hitam, rengginang, bubur ketan hitam, atau hanya direbus dan ditaburi parutan kelapa.

Pada penelitian sebelumnya, telah dilakukan isolasi bakteri asam laktat yang mempunyai kemampuan untuk menghidrolisis antosianin beras ketan hitam. Bakteri ini terindentifikasi sebagai Pediococcus pentosaceus N11.16 (Suhartatik, dkk., 2014). Bakteri yang mempunyai originalitas yang tinggi karena diisolasi dari makanan tradisional asli Indonesia yaitu tape ketan. Karena merupakan bakteri dengan strain baru, maka informasi tentang bagaimana kemampuan tumbuh bakteri ini dalam medium basal (MRS, deMann Rogosa Sharp) yang mengandung antosianin beras ketan hitam sangat minim. Penelitian ini akan menguji tentang karakteristik fermentatif medium MRS yang mengandung antosianin beras ketan hitam, terutama pemantauan tentang jumlah sel, perubahan aktivitas antioksidan, total fenol, dan aktivitas enzim. Tujuan penelitian ini adalah untuk mempelajari perubahan aktivitas antioksidan antosianin beras ketan hitam selama fermentasi menggunakan $P$. pentosaceus N11.16 pada medium MRS termodifikasi.

\section{METODE PENELITIAN}

\section{Ekstraksi Antosianin dari Beras Ketan Hitam (Pramilih dkk., 2007)}

Beras ketan hitam diperoleh dari Balai Penelitian Padi Subang dan varietas yang digunakan adalah varietas Setail. Beras disosoh separo (gelontor, Jawa) kemudian ditepungkan hingga lolos ayakan 40 mesh. Ekstraksi dilakukan dengan cara maserasi dalam larutan asam sitrat 1:3 (b/v) selama 12 jam pada ruang gelap suhu $4^{\circ} \mathrm{C}$. Selama proses maserasi, dilakukan pengadukan menggunakan pengaduk magnet. Modifikasi dilakukan pada lama perendaman.

Setelah itu, dilakukan sentrifugasi pada $5000 \mathrm{rpm}$ suhu $4^{\circ} \mathrm{C}$ selama 5 menit. Supernatan yang didapat kemudian disaring menggunakan kertas saring. Sebelum digunakan lebih lanjut, ekstrak antosianin beras ketan hitam ini disimpan pada botol coklat dan ruang gelap suhu $-20^{\circ} \mathrm{C}$.

\section{Penyiapan Medium}

Media basal yang digunakan dalam pengujian ini adalah medium MRS broth (deMann Rogosa Sharp). Setiap 1 liter medium yang digunakan mengandung: pepton protease No. 3 sebanyak $1 \%$; beef extract $1 \%$; ekstrak yeast $0,5 \%$; polisorbat $800,1 \%$; ammonium sitrat $0,2 \%$; $\mathrm{Na}$ asetat $0,5 \%$; magnesium sulfat $0,01 \%$; mangan sulfat $0,005 \%$; dan dikalium fosfat $0,2 \%$. MRSm (MRS modifikasi) merupakan MRS yang diformulasi tanpa penambahan gula dan yeast ekstrak sedangkan MRSm+antosianin adalah MRSm dengan penambahan antosianin beras ketan hitam. Sterilisasi medium dilakukan menggunakan autoklaf (Hirayama, HL-Clave 25) pada suhu $121^{\circ} \mathrm{C}$ selama 15 menit. Dengan tidak adanya glukosa dalam medium, maka diharapkan bakteri asam laktat dipaksa untuk memotong ikatan glikosidik pada antosianin untuk menggunakan gula yang terikat pada struktur utama antosianin.

\section{Penyiapan Bakteri}

Bakteri asam laktat berumur 18 jam sebanyak $10^{9}$ sel diinokulasikan ke dalam media fermentasi. Starter disiapkan dengan cara menginokulasikan 3-5 ose isolat dalam $5 \mathrm{ml}$ media MRS broth dan diinkubasikan selama 18 jam. Massa sel kemudian dipanen dan dicuci menggunakan larutan isotonis 
sebanyak 2 kali. Pemisahan sel dan massa sel dilakukan dengan cara sentrifuse (Labofuge 200, Heraus) pada $3000 \mathrm{rpm}$ selama 15 menit. Sebanyak $0,25 \mathrm{~mL}$ bakteri yang mengandung $10^{9}$ $\mathrm{sel} / \mathrm{mL}$ kemudian ditambahkan pada $25 \mathrm{~mL}$ substrat fermentasi (1\% dari volume medium) (Avila dkk., 2009).

\section{Kondisi Fermentasi}

Fermentasi dilakukan pada suhu $37^{\circ} \mathrm{C}$ (Avila dkk., 2009) selama 20 jam menggunakan Erlenmeyer (ukuran 100 $\mathrm{mL}$, pyrex) dan dilakukan pemantauan terhadap kadar fenol, aktivitas antioksidan (DPPH dan FRAP), kadar antosianin, dan jumlah sel pembentuk asam. Pemantauan terhadap parameter-parameter tersebut dilakukan setiap 2 jam sekali hingga jam ke-20. Proses fermentasi dihentikan dengan cara menempatkan sampel ke dalam freezer suhu $-40^{\circ} \mathrm{C}$.

\section{Penghitungan Jumlah Bakteri Pembentuk Asam}

Penghitungan jumlah bakteri pembentuk asam dilakukan dengan menanam sampel dengan seri pengenceran tertentu pada media MRS (deMann Rogosa Sharp, Oxoid, USA) yang ditambah dengan $1 \% \mathrm{CaCO}_{3}$ dan diinkubasi pada suhu $37^{\circ} \mathrm{C}$ selama 48 jam.

\section{Analisis Kadar Fenol}

Analisis kadar fenol menggunakan metode Singleton dan Rossi (1965) yang dimodifikasi sesuai dengan jenis sampelnya, yaitu dilakukan dengan cara menambahkan $200 \mu \mathrm{L}$ sampel (medium fermentasi) dengan 1,8 mL 0,2 N larutan Folin Ciocalteau dan $1,8 \mathrm{~mL} 6 \% \mathrm{Na}_{2} \mathrm{CO}_{3}$ pada suhu kamar. Sebelum ditera pada $\lambda 760 \mathrm{~nm}$ (Shimadzu UV-1601), campuran divorteks terlebih dahulu dan didiamkan pada suhu kamar selama 1,5 jam. Kadar fenol dinyatakan dalam mg asam galat/100 mL sampel dengan menggunakan asam galat sebagai larutan standar dengan perlakuan analisis yang sama (Qiu dkk., 2010).

\section{Analisis Aktivitas Antioksidan (\% Penangkapan Radikal DPPH)}

Aktivitas antioksidan (DPPH) ditentukan dengan mencampur 0,2 mL sampel (medium fermentasi) dengan 3,8 $\mathrm{mL}$ larutan $1 \mathrm{mM}$ DPPH (dalam metanol) dan diinkubasi selama 1 jam pada suhu kamar serta kondisi gelap (Li dkk., 2007). Peneraan dilakukan pada panjang gelombang $515 \mathrm{~nm}$. Blanko dibuat dengan menggantikan sampel dengan aquades dengan volume yang sama. Persentase penangkapan radikal bebas dinyatakan dalam persentase penghambatan radikal bebas DPPH.

$\% \int$ Penangkapan DPPH =

$\frac{\text { Absorbansi DPPH }- \text { Absorbansi sampel }}{\text { Absorbansi DPPH }} \times 100 \%$

\section{Analisis Aktivitas Antioksidan Angka Ferrous Reducing Activity Power (FRAP)}

Analisis aktivitas antioksidan dihitung berdasarkan kemampuan untuk mereduksi ion $\mathrm{Fe}^{3+}$ (nilai FRAP) seperti metode yang telah dikemukakan oleh Wang dkk. (2009). Analisis dilakukan dengan cara mencampur $1 \mathrm{~mL}$ sampel dengan 0,05 $\mathrm{mL} 2 \mathrm{mM} \mathrm{FeCl}_{2}, 0,2 \mathrm{~mL} 5 \mathrm{mM}$ ferrozine, dan $2,75 \mathrm{~mL}$ aquades. Setelah divorteks, diamkan selama 10 menit pada kondisi gelap, campuran kemudian ditera pada $\lambda 562$ nm. Kemampuan antioksidan dinyatakan dalam persentase FRAP, dengan aquades sebagai blanko dan EDTA sebagai kontrol positif.

$\%$ FRAP value $=\frac{A 0-(\mathrm{A} 1-\mathrm{A} 2)}{\mathrm{Ao}_{0}} \times 100 \%$

Keterangan: $\mathrm{A}_{0}$ adalah absorbansi kontrol positif, $\mathrm{A}_{1}$ adalah absorbansi sampel, dan $\mathrm{A}_{2}$ adalah absorbansi blangko.

\section{HASIL DAN PEMBAHASAN}

Jumlah Sel $P$. pentosaceus N11.16 pada Medium MRSm+antosianin

Pediococcus pentosaceus N11.16 dapat tumbuh dan berkembang biak pada medium MRSm+antosianin (Gambar 1). Meskipun sampai pada jam ke-4 masih membutuhkan tahapan adaptasi, namun pada jam ke-6 sudah menunjukkan adanya penambahan jumlah sel. Hal yang sama juga terjadi pada sel $P$. pentosaceus N11.16 yang ditumbuhkan pada medium MRS, namun dengan jumlah sel yang lebih besar daripada pada medium MRSm+antosianin (setara dengan $25 \mathrm{mM}$ sianidin-3-glukosida) maupun MRSm (tanpa sumber karbon). Jumlah sel maksimum yang dapat dicapai pada medium MRS, MRSm+antosianin, dan MRSm berturutturut adalah $5,49 \times 10^{9} ; 5,24 \times 10^{10}$; dan $1,59 \times 10^{8} \mathrm{CFU} /$

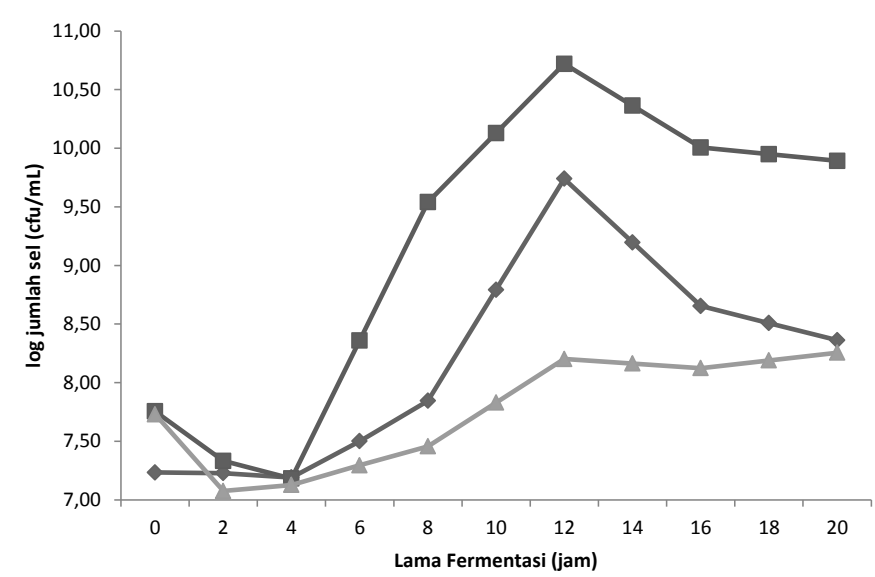

Gambar 1. Grafik pertumbuhan P. pentosaceus N11.16 pada medium MRS $(\square)$; MRSm + antosianin ( $)$; dan MRSm ( $\Delta)$ Keterangan: $\mathrm{x}=$ waktu inkubasi (jam); $y=\log \mathrm{CFU} / \mathrm{ml}$ 
ml. Jumlah sel maksimum ini semuanya terjadi pada jam ke12. Setelah 16 jam inkubasi, masing-masing jenis medium menunjukkan adanya penurunan jumlah sel dan mulai terjadi fase stasioner.

Pertumbuhan $P$. pentosaceus N11.16 dalam medium MRS menunjukkan kecenderungan yang hampir sama dengan pertumbuhan pada medium MRSm+antosianin dan MRSm. Pertumbuhan sel pada medium MRS lebih bagus (ditunjukkan dengan jumlah sel yang lebih banyak) daripada pertumbuhan pada medium MRSm+antosianin dan MRSm. Apabila dibandingkan antara pertumbuhan pada medium MRSm+antosianin dan MRSm maka dapat disimpulkan bahwa sel $P$. pentosaceus N11.16 dapat memotong ikatan glikosidik yang terdapat dalam antosianin dan memanfaatkan gula yang terikat pada struktur utama antosianin. Didukung dengan data pertumbuhan pada medium tanpa gula yang menunjukkan adanya kenaikan jumlah sel sejumlah $1 \log$ cycle. Pola fermentasi Lactobacillud plantarum RM71 pada medium yang mengandung glikosida quersetin yang dilakukan oleh Curiel dkk., (2010) menunjukkan bahwa penambahan quersetin pada medium fermentasi, dapat meningkatkan konsumsi gula. Ketidakberadaan gula dalam medium fermentasi akan menyebabkan adanya peningkatan fase lag (adaptasi) sekitar 5 jam lebih lama dibandingkan medium kontrol.

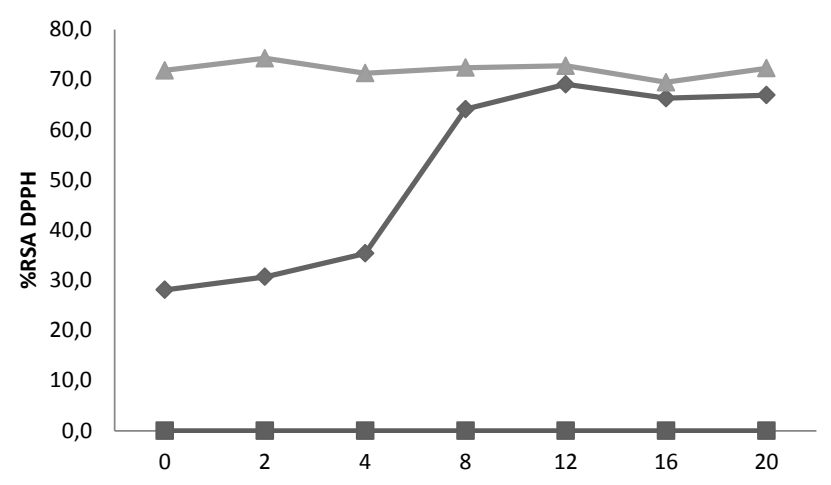

Gambar 2. Perubahan aktivitas antioksidan (\%RSA) medium selama fermentasi menggunakan $P$. pentosaceus $\mathrm{N} 11.16\left(37^{\circ} \mathrm{C}\right)$ Keterangan: $($ ) MRS; (๘) MRSm ; (^) MRSm + antosianin

Pertumbuhan pada medium MRSm menunjukkan adanya kenaikan jumlah sel meskipun medium yang dipakai tanpa gula. Hal ini disebabkan karena di dalam medium MRSm terdapat beef extract. Komponen ini mengandung sejumlah asam amino yang juga dapat digunakan sebagai sumber karbon pengganti apabila tidak tersedia gula di dalam medium.

Fermentasi antosianin beras ketan hitam menggunakan $P$. pentosaceus N11.16 dapat menyebabkan terjadinya perubahan aktivitas antioksidan (Gambar 2 dan Tabel 1). Fermentasi pada medium MRSm, menunjukkan \% RSA
DPPH nol (tidak terdeteksi). Medium MRSm terdiri dari pepton, beef extract, yeast extract, tween 80, ammonium sitrat, natrium asetat, magnesium sulfat, mangan sulfat, dan dikalium fosfat. Analisis aktivitas antioksidan berdasarkan \% RSA DPPH ini didasarkan pada kemampuan senyawa antioksidan dalam medium untuk menangkap radikal bebas DPPH. Analisis antioksidan dengan penentuan nilai FRAP, didasarkan pada kemampuan reduksi ion Ferri menjadi ion Ferro membentuk kompleks ferro yang berwarna (Benzie dan Starin, 1996) dan hasil analisisnya dapat dilihat pada Tabel 1.

Tabel 1. Perubahan aktivitas antioksidan (FRAP) medium selama fermentasi menggunakan $P$. pentosaceus N11.16

\begin{tabular}{cccr}
\hline \multirow{2}{*}{$\begin{array}{c}\text { Lama } \\
\text { fermentasi } \\
(\text { jam })\end{array}$} & MRS & \multicolumn{3}{c}{ MRSm } & \multicolumn{1}{c}{$\begin{array}{c}\text { MRSm }+ \\
\text { Antosianin }\end{array}$} \\
\cline { 2 - 4 } & $85,05 \pm 2,61^{\mathrm{k}}$ & $70,70 \pm 2,83^{\mathrm{j}}$ & $4,80 \pm 2,26^{\mathrm{a}}$ \\
2 & $68,85 \pm 3,61^{\mathrm{ij}}$ & $71,80 \pm 2,83^{\mathrm{j}}$ & $15,53 \pm 0,05^{\mathrm{cd}}$ \\
4 & $90,80 \pm 3,96^{\mathrm{1}}$ & $68,45 \pm 0,35^{\mathrm{ij}}$ & $2,00 \pm 0,57^{\mathrm{a}}$ \\
8 & $\mathrm{ND}$ & $65,35 \pm 0,21^{\mathrm{i}}$ & $36,75 \pm 0,21^{\mathrm{e}}$ \\
12 & $0,80 \pm 1,13^{\mathrm{a}}$ & $55,90 \pm 0,00^{\mathrm{g}}$ & $19,25 \pm 3,46^{\mathrm{d}}$ \\
16 & $43,60 \pm 1,56^{\mathrm{f}}$ & $44,70 \pm 1,13^{\mathrm{f}}$ & $9,80 \pm 1,70^{\mathrm{b}}$ \\
20 & $60,70 \pm 0,00^{\mathrm{h}}$ & $18,85 \pm 0,92^{\mathrm{d}}$ & $12,30 \pm 4,95^{\mathrm{bc}}$ \\
\hline
\end{tabular}

Ket: Angka yang diikuti notasi huruf yang tidak sama berarti berbeda nyata pada taraf signifikansi $5 \%$

Berbeda dengan hasil analisis aktivitas antioksidan dengan metode penangkapan radikal bebas, hasil analisis berdasarkan kemampuan mereduksi ion Ferri memberikan hasil yang sangat variatif. Dalam medium MRSm menunjukkan adanya kemampuan untuk mereduksi ion Ferri, dengan angka FRAP yang tergolong tinggi, yaitu antara 18,85 hingga 70,70\%. Medium MRSm+antosianin beras ketan hitam menunjukkan angka FRAP yang tergolong rendah, yaitu antara 2,00 hingga 36,75\%. Angka FRAP tertinggi dicapai saat fermentasi selama 4 jam menggunakan medium MRS. Pada jam ke-8 dengan medium MRS, angka FRAP tidak terdeteksi dan kembali menunjukkan aktivitas antioksidan lagi pada jam ke-12.

Berdasarkan hasil pengujian aktivitas antioksidan (FRAP), maka dapat dilihat bahwa secara keseluruhan, baik jenis medium fermentasi maupun waktu fermentasi tidak memberikan pengaruh nyata terhadap kemampuan mereduksi ion Fe. Beberapa spesies anggota bakteri asam laktat mempunyai kemampuan untuk memetabolisme komponen fenol (Rodriguez dkk., 2009) namun ada juga beberapa spesies yang tidak memetabolisme komponen fenol (Curiel dkk., 2010). Oleh karena itu, terdapat kemungkinan terjadinya 
perubahan kadar fenol yang diikuti dengan adanya perubahan aktivitas antioksidan.

Tabel 2. Perubahan total fenol selama fermentasi menggunakan $P$. pentosaceus N11.16

\begin{tabular}{|c|c|c|c|c|}
\hline \multirow{2}{*}{$\begin{array}{c}\text { Lama } \\
\text { fermentasi } \\
\quad \text { (jam) }\end{array}$} & \multicolumn{4}{|c|}{ Total fenol (mg asam galat/100 ml) pada jenis medium: } \\
\hline & MRS & & MRSm & $\begin{array}{c}\text { MRSm+ } \\
\text { antosianin }\end{array}$ \\
\hline 0 & $454,55 \pm 3,18$ & $\mathrm{i}$ & $238,05 \pm 1,06$ a & $551,55 \pm 0,351$ \\
\hline 2 & $420,80 \pm 2,12$ & h & $249,30 \pm 2,12 b$ & $583,05 \pm 2,47 \mathrm{~m}$ \\
\hline 4 & $416,55 \pm 1,77$ & h & $243,05 \pm 2,47$ a & $544,30 \pm 2,83 \mathrm{k}$ \\
\hline 8 & $398,30 \pm 2,12$ & e & $253,55 \pm 2,47 \mathrm{~b}$ & $544,30 \pm 2,12 \mathrm{k}$ \\
\hline 12 & $366,80 \pm 2,12$ & d & $241,55 \pm 1,77$ a & $536,80 \pm 1,41 j$ \\
\hline 16 & $404,30 \pm 3,53$ & f & $260,30 \pm 3,53 \mathrm{~b}$ & $584,05 \pm 1,06^{\mathrm{m}}$ \\
\hline 20 & $411,80 \pm 0,71$ & $\mathrm{~g}$ & $239,05 \pm 2,47$ a & $551,80 \pm 2,12{ }^{1}$ \\
\hline
\end{tabular}

Ket: Angka yang diikuti notasi huruf yang tidak sama berarti berbeda nyata pada taraf signifikansi 5\%

Total fenol (Tabel 2) medium hasil fermentasi mempunyai kecenderungan yang lebih rendah untuk medium MRSm (rata-rata 246,41 $\mathrm{mg}$ asam galat/100 mL medium), apabila dibandingkan dengan medium MRS (410,44 mg asam galat/100 $\mathrm{mL}$ medium) dan MRSm+antosianin (556,55 $\mathrm{mg}$ asam galat/100 $\mathrm{mL}$ medium). Total fenol yang tertinggi terdapat pada medium MRSm+antosianin. Hal ini disebabkan karena adanya penambahan antosianin dalam medium MRSm+antosianin. Lama fermentasi terbukti tidak mempunyai pengaruh nyata pada total fenol medium fermentasi. Meskipun masing-masing menunjukkan notasi huruf yang berbeda antar perlakuan, namun total fenol medium fermentasi tidak menunjukkan adanya kecenderungan tertentu dengan semakin lamanya waktu fermentasi. Hasil yang sama ditunjukkan pada fermentasi minuman berbasis susu yang disuplementasi dengan komponen fenol dari ekstrak minyak olive (Servili dkk., 2011).

Total fenol terendah dicapai pada medium fermentasi MRSm sebelum fermentasi (0 jam) yaitu sebesar 238,05 mg asam galat/100 ml medium, sedangkan total fenol tertinggi terdapat pada medium fermentasi MRSm+antosianin, yaitu sebesar 548,05 mg asam galat/100 mL medium. Medium MRSm+antosianin mempunyai total fenol yang lebih tinggi dibandingkan dengan 2 jenis medium yang lain disebabkan karena adanya tambahan antosianin di dalam medium.

Meskipun terdapat beda nyata pada masing-masing jam pengamatan, namun total fenol cenderung naik turun selama fermentasi. Degradasi antosianin diduga dapat menghasilkan senyawa atau komponen yang lebih sederhana dan total fenol cenderung stabil. Medium MRSm mengandung sejumlah komponen fenol, kemungkinan disebabkan adanya komponen di dalam medium yang mempunyai struktur fenol di dalamnya, seperti asam amino-asam amino di dalam beef extract (Corry dkk., 2003).

Tabel 3. Perubahan aktivitas enzim $\beta$ glukosidase selama fermentasi menggunakan $P$. pentosaceus N11.16

\begin{tabular}{cccc}
\hline \multirow{2}{*}{$\begin{array}{c}\text { Lama } \\
\text { fermentasi } \\
\text { (jam) }\end{array}$} & MRS & MRSm & $\begin{array}{c}\text { MRSm+ } \\
\text { antosianin }\end{array}$ \\
\cline { 2 - 4 } & $0.051+0.001^{\mathrm{c}}$ & $0,046+0,001^{\mathrm{a}}$ & $0,063+0,000^{\mathrm{i}}$ \\
2 & $0,053+0,001^{\text {de }}$ & $0,050+0,001^{\mathrm{c}}$ & $0,059+0,001^{\mathrm{h}}$ \\
4 & $0,053+0,000^{\text {de }}$ & $0,047+0,000^{\text {a }}$ & $0,057+0,001^{\mathrm{g}}$ \\
8 & $0,053+0,000^{\text {de }}$ & $0,051+0,001^{\mathrm{c}}$ & $0,054+0,002^{\text {ef }}$ \\
12 & $0,048+0,000^{\mathrm{b}}$ & $0,060+0,000^{\mathrm{h}}$ & $0,067+0,000^{\mathrm{j}}$ \\
16 & $0,054+0,001^{\text {ef }}$ & $0,058+0,001^{\mathrm{g}}$ & $0,055+0,001^{\mathrm{f}}$ \\
20 & $0,052+0,000^{\text {cd }}$ & $0,052+0,001^{\text {cd }}$ & $0,061+0,001^{\mathrm{h}}$ \\
\hline
\end{tabular}

Ket: Angka yang diikuti notasi huruf yang tidak sama berarti berbeda nyata pada taraf signifikansi $5 \%$

Satu unit aktivitas enzim didefinisikan sebagai jumlah $\beta$ glukosidase yang melepaskan $1 \mathrm{mM} \rho$ nitrofenol dari substrat per menit

Aktivitas enzim $\beta$ glukosidase (Tabel 3) yang dihasilkan oleh $P$. pentosaceus N11.16 cenderung mengalami perubahan selama fermentasi. Secara umum, aktivitas enzim $\beta$ glukosidase pada medium MRS dan MRSm (rata-rata 0.052 unit/mg protein) mempunyai nilai yang lebih rendah daripada MRSm+antosianin (0,560 unit/mg protein). Aktivitas enzim $\beta$ glukosidase yang terendah, terdapat pada sampel medium fermentasi MRSm (0 jam) sebesar 0,046 unit/mg protein sedangkan aktivitas enzim terbesar terdapat pada medium fermentasi MRSm+antosianin setelah difermentasi selama 12 jam, yaitu sebesar 0,067 unit/mg protein.

Medium MRSm menunjukkan aktivitas enzim yang tinggi setelah difermentasi selama 12 jam, yaitu sebesar 0,060 unit/mg protein sama halnya dengan medium MRSm+antosianin yang juga mencapai aktivitas enzim tertinggi pada jam ke-12. Berbeda dengan aktivitas enzim $\beta$ glukosidase yang pada medium MRS yang baru mencapai aktivitas enzim $\beta$ glukosidase tertinggi setelah mengalami fermentasi selama 16 jam. Sejalan dengan hasil penelitian dari Jeon dkk. (2002) yang menunjukkan bahwa aktivitas enzim $\beta$ glukosidase mencapai maksimal setelah difermentasi selama 12 jam.

\section{KESIMPULAN}

Bakteri $P$. pentosaceus N11.16 mampu tumbuh dengan baik dalam medium MRS yang mengandung antosianin beras ketan hitam. Aktivitas antioksidan (\%RSA DPPH) mengalami kenaikan selama fermentasi mulai jam ke 8 sedangkan angka FRAP mengalami penurunan terutama pada jam ke-4. 
Total fenol, aktivitas antioksidan (\%RSA DPPH dan angka FRAP) medium MRSm+antosianin cenderung lebih tinggi daripada MRSm atau kontrol (MRS). Aktivitas enzim $\beta$ glukosidase sel bakteri cenderung lebih tinggi pada medium MRSm+antosianin daripada MRSm atau kontrol (MRS).

\section{UCAPAN TERIMA KASIH}

Penulis mengucapkan terima kasih kepada Ditjen Dikti, yang telah membantu untuk terlaksananya penelitian ini melalui Program Hibah Bersaing 2013 dengan nomor kontrak: 580/S9/K/2012 tertanggal 17 Maret 2012.

\section{DAFTAR PUSTAKA}

Avila, M., Hidalgo, M., Moreno, C.S., Pelaez, C., Requena, T. dan de-Pascuel Teresa, S. (2009). Bioconversion of anthocyanin glycosides by Bifidobacteria and Lactobacillus. Food Research International 42: 14531461.

Benzie, I.F.F. dan Strain, J.J. (1996). The ferric reducing ability of plasma (FRAP) as a measure of "antioxidant power": the FRAP assay. Analytical Biochemistry 239: $70-76$.

Bagchi, D., Sen, C.K., Bagchi, M. dan Atalay, M., (2004). Anti-angiogenic, antioxidant, and anticarcinogenic properties of a novel anthocyanin-rich berry extract formula, Biochemistry 69: 75-80.

Corry, J.E.L., Curtis, G.D.W. dan Baird, R.M. (2003). Handbook of Culture Media for Food Microbiology. Elsevier, New York.

Curiel, J.A., Munoz, R. dan de-Felipe, F.L. (2010). pH and dose-dependet effects of quercetin on the fermentation capacity of Lactobacillus plantarum. Food Science and Technology 43: 926-933.

Ghiselli, A., Nardini, M., Baldi, A. dan Scaccini, C. (1998). Antioxidant activity of different phenolic fractions separated from an Italian red wine. Journal of Agricultural and Food Chemistry 46: 361-367.

Itani, T. dan Ogawa, M. (2004). History and recent trends of red rice in Japan. Nippon Sakumotsu Gakkai Kiji 73: 137-147.

Jeon, K.S., Ji, G.E. dan Hwang, I.K. (2002). Assay of $\beta$-glucosidase activity of Bifidobacteria and hydrolysis of isoflavone glycosides Bifidobacterium $s p$ Int-57 in soymilk fermentation. Journal of Microbiology and Biotechnology 12: 8-13.
Kamei, H., Hashimoto, Y., Koide, T., Kojima, T. dan Hasegawa, M. (1998). Anti-tumor effect of methanol extracts from red and white wines. Cancer Biotherapy and Radiopharmacology 13: 447-452.

Kano, M., Takayanagi, T., Harada, K., Makino, K. dan Ishikawa, F. (2005). Antioxidative activity of anthocyanins from purple sweet potato, Ipomoea batatas cultivar Ayamurasaki. Biochemistry 69: 979-988.

Katsube, N., Iwashita, K., Tsushida, T., Yamaki, K. dan Kobori, M. (2003). Journal of Agricultural and Food Chemistry 51: 68-72.

Keppler, K. dan Humpf, H.U. (2005). Metabolism of anthocyanins and their phenolic degradation products by the intestinal microflora. Bioorganic dan Medicinal Chemistry 13: 5195-5205.

Li, W., Pickard, M, dan Beta T. (2007). Effect of thermal processing on antioxidant properties of purple wheat bran. Food Chemistry 104: 1080-1086.

Ling, W.H., Cheng, Q.X., Ma, J. dan Wang, T. (2001). Red and black rice decrease atherosclerotic plaque formation and increase antioxidant status in rabbits. Journal of Nutrition 131: 1421-1426.

Manach, C., Williamson, G., Morand, C., Scalbert, A. dan Remesy, C. (2005). Bioavailability and bioefficacy of polyphenols in humans, review of 97 bioavailability studies. American Journal of Clinical Nutrition 81: 230S-242S.

Matsumoto, H., Inaba, H., Kishi, M., Tominaga S., Hirayama M. dan Tsuda T. (2001). Orally administered delphinidin-3-rutinoside and cyanidin-3-rutinoside are directly absorbed in rats and humans and appear in the blood as the intact forms. Journal of Agricultural and Food Chemistry 49: 1546-1551.

Matsuda, S., Norimoto, F., Matsumoto, Y., Ohba, R., Teramoto, Y. dan Ohta, N. (1994). Solubilization of novel isoflavone glycoside-hydrolyzing -glucosidase from Lactobacillus casei subsp rhamnosus. Journal of fermentation and bioengineering 77: 439-441.

Matsui, T., Ebuchi, S. dan Kobayashi, M. (2002). Antihyperglycemic effect of diacylated anthocyanin derived from Ipomoea batatas cultivar Ayamurasaki can be achieved through the Alpha-glucosidase inhibitory action. Journal of Agricultural and Food Chemistry 50: 7244-7248.

McGhie, T.K., Aiinge, G.D., Barnett, L.E., Cooney, J.M. dan Jensen, D.J. (2003). Anthocyanin glycosides from berry fruit are absorbed and excreted unmetabolized by 
both humans and rats. Journal of Agricultural and Food Chemistry 51: 4539-4548.

Nielsen, I.L., Dragsted, L.O., Ravn-Haren, G., Freese R. dan Rasmussen, S.E. (2003). Absorption and excretion of balck currant anthocyanins in humans and watanabe heritable hyperlipidemic rabbits. Journal of Agricultural and Food Chemistry 51: 2813-2820.

Oki, T., Masuda, M., Furuta, S., Nishiba, Y., Terahara, N. dan Suda, I. (2002). Involvement of anthocyanins and other phenolics compound in radical-scavenging activity of purple-fleshed sweet potato cultivars. Journal of Food Science 67: 1752-1756.

Otieno, D.O., Ashton, J.F. dan Shah, N.P. (2005). Stability of -glucosidase activity produced by Bifidobacterium and Lactobacillus spp in fermented soy milk during processing and storage. Journal of Food Science 70: 236-241.

Pramilih, W.N., Astuti, M. dan Hastuti, P. (2007). Ekstraksi Antosianin Beras Hitam (Oryza sativa L indica) Menggunakan Pelarut Air, Pengaruh Lama Maserasi, Rasio Bahan/Pelarut, Jumlah Ekstraksi Berulang dan Suhu terhadap Antosianin yang Terekstrak. Skripsi. Program Studi Teknologi Pengolahan Hasil Pertanian. Fakultas Teknologi Pertanian. Universitas Gadjah Mada, Yogyakarta.

Perera, A. dan Jansz, E. R., (2000). Preliminary investigations on the red pigment in rice and its effect on glucose release from rice starch, Journal of Natural Science Foundation Sri Lanka 28: 185-192.

Qiu, Y., Liu, Q. dan Beta, T. (2010). Antioxidant properties of commercial wild rice and analysis of soluble and insoluble phenolics acids. Food Chemistry 121: 140147.

Rodriguez, H., Curiel, J.A., Landete, J.M., Rivas, B.L., deFelipe, F.L., Gomez-Cordoves, C., Mancheno, J.M. dan Munoz, R. (2009), Food phenolics and lactic acid bacteria, International Journal of Food Microbiology 132: 79-90.

Servili, M., Rizzello, C.G., Tatichi, A., Espoto, S., Urbani, S., Mazzacane, F., Di Maio, I., Selvaggini, R., Gobbetti, M. dan Di-Cagno, R. (2011). Fucntional milk beverage fortified with phenolic compounds extracted from olive vegetation water, and fermented with functional lactic acid bacteria. International Journal of Food Microbiology 147: 45-52.

Singleton, V.L. dan Rossi, J.A. (1965). Colorimetry of total phenolics with phosphomolybdic-phosphotungstic acid reagents. American Journal of Enology Viticulture 16: 144-158.

Suhartatik, N., Cahyanto, M.N., Raharjo., S. dan Miyashita, M. (2014). Isolation and identification of lactic acid bacteria producing $\beta$ glucosidase from Indonesian fermented food. International Journal of Food Research. 21: $937-942$

Wang, Li-Shu dan Stoner, G.D. (2009). Anthocyanin and their role in cancer prevention, Cancer Letter 269: 281-290.

Wang, T., Jonsdottir, R. dan Olafsdottir, G. (2009). Total phenolics compounds, radical scavenging and metal chelation of extracts from Icelandic seaweeds. Food Chemistry 116: 240-248. 